\title{
Perceived Impact of Coconut Climbing Equipment on Income Generation of Rural Youths in Karnataka India
}

\author{
M. Venkatesha, D. Raghupathi* and V. B. Sanath Kumar \\ College of Agriculture, VC Farm, Mandya, Karnataka, India \\ *Corresponding author
}

\begin{abstract}
A B S T R A C T
Rural youth are showing less interest in farming as it not provider of employment round the year. They are migrating to Urban cities/towns in search of jobs for their income earning and livelihood. This phenomenon badly affected the agriculture sector not only in Karnataka state but across the India. To provide skill training for the rural youth Govt. launched several initiatives among them imparting skill trainings is one. The coconut Development Board (CDB) organized a vacation skill training to rural youth to retain the youth in agriculture. One such program was organized in association with KVKs across the Country. Similar kind of program was done by KVK, Mandya, Karnataka during 201314. A total of 220 youths were trained using coconut climbing equipment to harvest tender and matured nuts. A research study was conducted during 2018 in Mandya district with an objective of finding the perceived impact of coconut climbing equipment on income generation by respondents. A pretested and structured interview schedule was developed to collect data from respondents. The results of the study revealed that majority of the respondents had earned Rs. 10,000 per annum by using coconut climbing equipment. Few respondents travelled outside their home place up to $50 \mathrm{kms}$ distance for income earning. Regarding constraints expressed in using of equipment, many of the respondents expressed health problem such as knee, thigh and shoulder pain while using equipment and the utility of coconut climbing equipment was seasonal and not regular to earn income.
\end{abstract}

\section{Introduction}

The labour scarcity is a major impediment to conduct timely farm operations in agriculture. Similarly, Coconut palm being an important commercial horticulture crop of Mandya district, Karnataka State, the farmers of coconut garden are facing scarcity of labour for harvesting the tender and matured nuts. The rural youth are migrating to the cities from the rural areas in search of jobs for their livelihood (Yalesi, 2016). As they perceived that farming is not a full time regular employment provider for their livelihood and the profits accrued from this are meager and they often experienced losses because of climate vagaries, less marketable produce etc. (Latha, 2003). This kind of impact created scarcity of labour in the rural area and swarming migration to the cities/towns. To retain the youth in rural areas the Government launched skill development programs to 
provide self employment to rural youth of India. With this, the Coconut Development Board (CDB) has initiated an Innovative training programme viz., "Friends of Coconut Tree" (FOCT) in association with Krishi Vigyan Kendras (KVKs) and National Rural Livelihood Mission (NRLM), Government of Karnataka to develop a professional group of youth to provide employment through skill training for harvesting of coconuts. With this background the KVK, Mandya has organized training program for youths of Mandya district during 2013-14 for period of one week to 220 youths in nine batches covering seven taluks of Mandya district (KVK Training Manual 2013). The youth were provided a coconut climbing equipment at free of cost as an incentive for them to seek selfemployment. To throw a light on this study was conducted to know to what extent the training was useful for the rural youth for their income generation by using the coconut climbing equipment. The objectives of the study are: to find out the extent of income earned through nut harvesting; the distance travelled by the trainees to earn income; to elucidate the constraints experienced by the respondents in using the coconut climbing equipment; and to find out the association between personal characters and the income generation of respondents.

\section{Materials and Methods}

The study was conducted in Mandya district, which has seven talukas viz., Mandya, Maddur, Pandavapura, Srirangapatna, Nagamangala, Malavalli and Krishnarajapet. The Krishi Vigyan Kendra (KVK) Mandya has conducted "FOCT- Palm climbing and plant protection" training programme to 220 youths of the district during 2013-14. From this 220 population, 70 trainees as respondents representing all the seven talukas of Mandya district, Karnataka were selected randomly through cluster sampling method. The research design set was Before and After evaluation type (Kerlinger, 1964).The variables selected for the study were 'Income generation' as dependent variable and 'Family size' 'Education level' and 'Land holding' of the respondent as the independent variables. The dependent variable 'income generation' was measured considering the income range minimum and maximum of the respondent and were categorized as rich, middle and poor. The income generated per year was calculated. The variable distance travelled by the respondent was measured in kilometer $(\mathrm{km})$ from native place to place worked for harvesting of nuts for his income generation. The independent variable 'Family size' was measured by considering the number of members lived under single roof. They were categorized as Joint (>10 members), medium (5 to 10 members) and the nucleus (up to 5 members wife, husband and 3 children) categories. The 'Education level' variable was grouped as primary, middle and high school and college level. The 'Land holding' variable was measured by considering the extent of land owned by them and were categorized big farmers ( $>5$ acres), small farmers (2.5 to 5.0 acres) and marginal farmers ( $<2.5$ acres). The extent of association between the dependent variable income generation and with that of three independent variables was assessed by applying the chi square statistical test. Considering the study objectives, an alternate hypothesis of significant association between the dependent variable 'income generation' with that of three independent variables was set. The data were collected from the respondents by administering a pre-tested and structured interview schedule, the opinions and date were based on memory and perception (Adivi Reddy, 1977). Care was taken to avoid onlookers and other external disturbances influence while collecting the data. Simple statistical tools such as frequency and per cent were used to analyze the data and to draw the inference (David j. Sheskin, 2011). 


\section{Results and Discussion}

\section{Income generated through harvesting of matured nuts}

The results (Table-1) indicated that majority of the respondents $(85.71 \%)$ earned an annual income less than Rs. 10,000 per year by using the coconut climbing equipment for harvesting of matured nuts. However, some respondents $(8.57 \%$ and $5.72 \%)$ have earned an annual income in a range of Rs. 10,001 to 50,000 and Rs. $1,00,001$ to $1,50,000$ respectively for harvesting of matured nuts per anum (Graph-1). This implies that many of the respondents generated income through the use of coconut climbing equipment besides their agriculture activities throughout the year for their livelihood. The reason could be that they were not using the equipment for commercial purpose (Jayale, 1992).

\section{Distance travelled for income generation}

The study reveals that (Table 2 and Graph 2) only $15.73 \%$ of the respondents has travelled outside their home place in search of employment. Whereas $84.27 \%$ of the respondents could not travel at all. They got the employment in their home/native place itself. Among the travelers, many of them travelled the distance ranging from 1 to $50 \mathrm{~km}$ from their home place, as the distance within their reach and back to home on the same day.

\section{Constraints experienced by the respondents in using coconut climbing equipment}

Constraints experienced by the respondents (Table 3) implies that many of them $(42.85 \%)$ expressed health problem such as knee, thigh and shoulder pain at the initial period of operation because continues use of hands and legs simultaneously by using equipment while climbing the coconut palm. Some of the respondents also expressed that climatic conditions such as heavy rain, whirl wind, hot days etc., which did not favour them to go for using of equipment for harvesting of nuts.

At the same time many of the respondents (48.57\%) had expressed less health ailments or any aberrant climate problem using coconut climbing equipment for harvesting of nuts (Jaganathan et al., 2016) (Graph3). To infer that there was a mixed response of respondents regarding health problems while using the equipment.

\section{Association between income generation and family size of the respondents}

There was no significant association between income generation and family size of respondents (Table- 4 Chi square $=0.08 \mathrm{NS}$ ).

The probable reasons could be that the respondents; their irrespective of family size had not involved in using the equipment for income generation, this perhaps could be due to lack of skills in using of equipment and they might have engaged in other farm activities.

\section{Association between income generation and education level of the respondents}

There was no significant association between income generation and education level of respondents farmers (Table-5, Chi square $=0.48 \mathrm{NS}$ ). This implies that higher education had not helped the respondents in income generation by using the equipment.

They earned almost same income as that of lesser education level. Further, to climb coconut palm to harvest the nuts, higher education did not require as it involved a sharp skills and common sense while using equipment. 
Table.1 Impact of coconut climbing equipment on income generated by harvesting mature nuts

\begin{tabular}{|c|c|c|c|c|c|c|c|c|}
\hline $\begin{array}{c}\text { Income Range } \\
\text { (Rs.) }\end{array}$ & Mandya & Maddur & Pandavapura & $\begin{array}{c}\text { S. R. } \\
\text { Patna }\end{array}$ & Nagamangala & $\begin{array}{c}\text { K. R. } \\
\text { Pet }\end{array}$ & Malavalli & Total \\
\cline { 2 - 9 } & No. & No. & No. & No. & No. & No. & No. & No. \\
\hline $\mathbf{1 0 0 0 0}$ & 37 & 4 & 8 & 2 & 7 & 1 & 1 & 60 \\
& $(52.85)$ & $(5.71)$ & $(11.43)$ & $(2.86)$ & $(10.00)$ & $(1.43)$ & $(1.43)$ & $(85.71)$ \\
\hline $\mathbf{1 0 0 0 1}$ to 50000 & 1 & 0 & 1 & 0 & 1 & 2 & 1 & 6 \\
& $(1.43)$ & $(0.00)$ & $(1.43)$ & $(0.00)$ & $(1.43)$ & $(2.86)$ & $(1.43)$ & $(8.57)$ \\
\hline $\mathbf{5 0 0 0 1}$ to & 0 & 0 & 0 & 0 & 0 & 0 & 0 & 0 \\
\hline $\mathbf{1 0 0 0 0 0}$ & $(0.00)$ & $(0.00)$ & $(0.00)$ & $(0.00)$ & $(0.00)$ & $(0.00)$ & $(0.00)$ & $(0.00)$ \\
\hline $\mathbf{1 0 0 0 0 1}$ to & 1 & 0 & 3 & 0 & 0 & 0 & 0 & 4 \\
\hline $\mathbf{1 5 0 0 0 0}$ & $(1.43)$ & $(0.00)$ & $(4.29)$ & $(0.00)$ & $(0.00)$ & $(0.00)$ & $(0.00)$ & $(5.72)$ \\
\hline Total & 39 & 4 & 12 & 2 & 8 & 3 & 2 & 70 \\
& $(55.71)$ & $(5.71)$ & $(17.15)$ & $(2.86)$ & $(11.43)$ & $(4.29)$ & $(2.86)$ & $(100.00)$ \\
\hline
\end{tabular}

The figures in the parenthesis indicate the percentage values

Table.2 Distance travelled for income generation by using coconut climbing equipment

\begin{tabular}{|c|c|c|c|c|c|c|c|c|}
\hline \multirow[t]{2}{*}{$\begin{array}{c}\text { Distance } \\
(\mathbf{k m})\end{array}$} & Mandya & Maddur & Pandavapura & $\begin{array}{l}\text { S. R. } \\
\text { Patna }\end{array}$ & Nagamangala & $\begin{array}{c}\text { K. R. } \\
\text { Pet }\end{array}$ & Malavalli & Total \\
\hline & No. & No. & No. & No. & No. & No. & No. & No. \\
\hline $\begin{array}{l}\text { Zero (Not } \\
\text { travelled) }\end{array}$ & $\begin{array}{c}35 \\
(50.00)\end{array}$ & $\begin{array}{c}3 \\
(4.29)\end{array}$ & $\begin{array}{c}8 \\
(11.43)\end{array}$ & $\begin{array}{c}8 \\
(11.43)\end{array}$ & $\begin{array}{c}2 \\
(2.86)\end{array}$ & $\begin{array}{c}2 \\
(2.86)\end{array}$ & $\begin{array}{c}1 \\
(1.43)\end{array}$ & $\begin{array}{c}59 \\
(84.28)\end{array}$ \\
\hline 1 to 25 & $\begin{array}{c}3 \\
(4.29)\end{array}$ & $\begin{array}{c}1 \\
(1.43)\end{array}$ & $\begin{array}{c}1 \\
(1.43)\end{array}$ & $\begin{array}{c}0 \\
(0.00)\end{array}$ & $\begin{array}{c}0 \\
(0.00)\end{array}$ & $\begin{array}{c}1 \\
(1.43)\end{array}$ & $\begin{array}{c}0 \\
(0.00)\end{array}$ & $\begin{array}{c}6 \\
(8.57)\end{array}$ \\
\hline 26 to 50 & $\begin{array}{c}0 \\
(0.00)\end{array}$ & $\begin{array}{c}0 \\
(0.00)\end{array}$ & $\begin{array}{c}2 \\
(2.86)\end{array}$ & $\begin{array}{c}0 \\
(0.00)\end{array}$ & $\begin{array}{c}0 \\
(0.00)\end{array}$ & $\begin{array}{c}0 \\
(0.00)\end{array}$ & $\begin{array}{c}1 \\
(1.43)\end{array}$ & $\begin{array}{c}3 \\
(4.29)\end{array}$ \\
\hline 51 to 75 & $\begin{array}{c}1 \\
(1.43)\end{array}$ & $\begin{array}{c}0 \\
(0.00)\end{array}$ & $\begin{array}{c}0 \\
(0.00)\end{array}$ & $\begin{array}{c}0 \\
(0.00)\end{array}$ & $\begin{array}{c}0 \\
(0.00)\end{array}$ & $\begin{array}{c}0 \\
(0.00)\end{array}$ & $\begin{array}{c}0 \\
(0.00)\end{array}$ & $\begin{array}{c}1 \\
(1.43)\end{array}$ \\
\hline 76 to 100 & $\begin{array}{c}0 \\
(0.00)\end{array}$ & $\begin{array}{c}0 \\
(0.00)\end{array}$ & $\begin{array}{c}1 \\
(1.43)\end{array}$ & $\begin{array}{c}0 \\
(0.00)\end{array}$ & $\begin{array}{c}0 \\
(0.00)\end{array}$ & $\begin{array}{c}0 \\
(0.00)\end{array}$ & $\begin{array}{c}0 \\
(0.00)\end{array}$ & $\begin{array}{c}1 \\
(1.43)\end{array}$ \\
\hline Total & $\begin{array}{c}4 \\
(5.71)\end{array}$ & $\begin{array}{c}1 \\
(1.43)\end{array}$ & $\begin{array}{c}4 \\
(5.72)\end{array}$ & $\begin{array}{c}0 \\
(0.00)\end{array}$ & $\begin{array}{c}0 \\
(0.00)\end{array}$ & $\begin{array}{c}1 \\
(1.43)\end{array}$ & $\begin{array}{c}1 \\
(1.43)\end{array}$ & $\begin{array}{c}11 \\
(15.73)\end{array}$ \\
\hline
\end{tabular}

The figures in the parenthesis indicate the percentage values

Table.3 Constraints experienced by the respondents in using coconut climbing equipment

$\mathrm{n}=70$

\begin{tabular}{|c|c|c|c|c|c|c|c|c|}
\hline \multirow{2}{*}{$\begin{array}{l}\text { Const- } \\
\text { raints }\end{array}$} & Mandya & Maddur & Pandavapura & S.R. Patna & Nagamangala & K.R.Pet & Malavalli & Total* \\
\hline & No. & No. & No. & No. & No. & No. & No. & No. \\
\hline Health Problem & $\begin{array}{c}18 \\
(25.71)\end{array}$ & $\begin{array}{c}0 \\
(0.00)\end{array}$ & $\begin{array}{c}1 \\
(1.43)\end{array}$ & $\begin{array}{c}0 \\
(0.00)\end{array}$ & $\begin{array}{c}7 \\
(10.00)\end{array}$ & $\begin{array}{c}3 \\
(4.29)\end{array}$ & $\begin{array}{c}1 \\
(1.43)\end{array}$ & $\begin{array}{c}30 \\
(42.85)\end{array}$ \\
\hline Aberrant climate & $\begin{array}{c}2 \\
(2.86)\end{array}$ & $\begin{array}{c}0 \\
(0.00)\end{array}$ & $\begin{array}{c}2 \\
(2.86)\end{array}$ & $\begin{array}{c}1 \\
(1.43)\end{array}$ & $\begin{array}{c}1 \\
(1.43)\end{array}$ & $\begin{array}{c}0 \\
(0.00)\end{array}$ & $\begin{array}{c}0 \\
(0.00)\end{array}$ & $\begin{array}{c}6 \\
(8.57)\end{array}$ \\
\hline $\begin{array}{l}\text { No health or } \\
\text { climate problem }\end{array}$ & $\begin{array}{c}19 \\
(27.14)\end{array}$ & $\begin{array}{c}4 \\
(5.71)\end{array}$ & $\begin{array}{c}9 \\
(12.85)\end{array}$ & $\begin{array}{c}1 \\
(1.43)\end{array}$ & $\begin{array}{c}0 \\
(0.00)\end{array}$ & $\begin{array}{c}0 \\
(0.00)\end{array}$ & $\begin{array}{c}1 \\
(1.43)\end{array}$ & $\begin{array}{c}34 \\
(48.57)\end{array}$ \\
\hline
\end{tabular}

The figures in the parenthesis indicate the percentage values

*multiple responses 
Table.4 Association between income generation and family size of the respondents

\begin{tabular}{|l|c|c|c|c|}
\hline \multirow{2}{*}{ Family size } & \multicolumn{3}{|c|}{ Income generation groups } & \multirow{2}{*}{ Total } \\
\cline { 2 - 4 } & Rich & Middle & Poor & \\
\hline Joint & 5 & 7 & 8 & 20 \\
\hline Medium & 4 & 6 & 7 & 17 \\
\hline Nucleus & 16 & 11 & 6 & 33 \\
\hline Total & $\mathbf{2 5}$ & $\mathbf{2 4}$ & $\mathbf{2 1}$ & $\mathbf{7 0}$ \\
\hline
\end{tabular}

Chi square $=0.08 \mathrm{NS}$

Table.5 Association between income generation and education level of the respondents $\mathrm{n}=70$

\begin{tabular}{|l|c|c|c|c|}
\hline \multirow{2}{*}{ Education level } & \multicolumn{3}{|c|}{ Income generation groups } & \multirow{2}{*}{ Total } \\
\cline { 2 - 5 } & Rich & Middle & Poor & \\
\hline College and above & 10 & 9 & 6 & 25 \\
\hline High school & 10 & 8 & 6 & 24 \\
\hline Primary school & 5 & 7 & 9 & 21 \\
\hline \multicolumn{1}{|c|}{ Total } & $\mathbf{2 5}$ & $\mathbf{2 4}$ & $\mathbf{2 1}$ & $\mathbf{7 0}$ \\
\hline
\end{tabular}

Chi square $=0.48 \mathrm{NS}$

Table.6 Association between income generation and land holding of the respondents

\begin{tabular}{|c|c|c|c|c|}
\hline \multirow[t]{2}{*}{ Land holding } & \multicolumn{3}{|c|}{ Income generation groups } & \multirow[t]{2}{*}{ Tota } \\
\hline & Rich & Middle & Poor & \\
\hline Big & 13 & 8 & 6 & 27 \\
\hline Small & 6 & 11 & 7 & 24 \\
\hline Marginal & 6 & 5 & 8 & 19 \\
\hline Total & 25 & 24 & 21 & 70 \\
\hline
\end{tabular}

Chi square $=0.62 \mathrm{NS}$

Graph.1 Impact of coconut climbing equipment on income generated by harvesting matured nuts

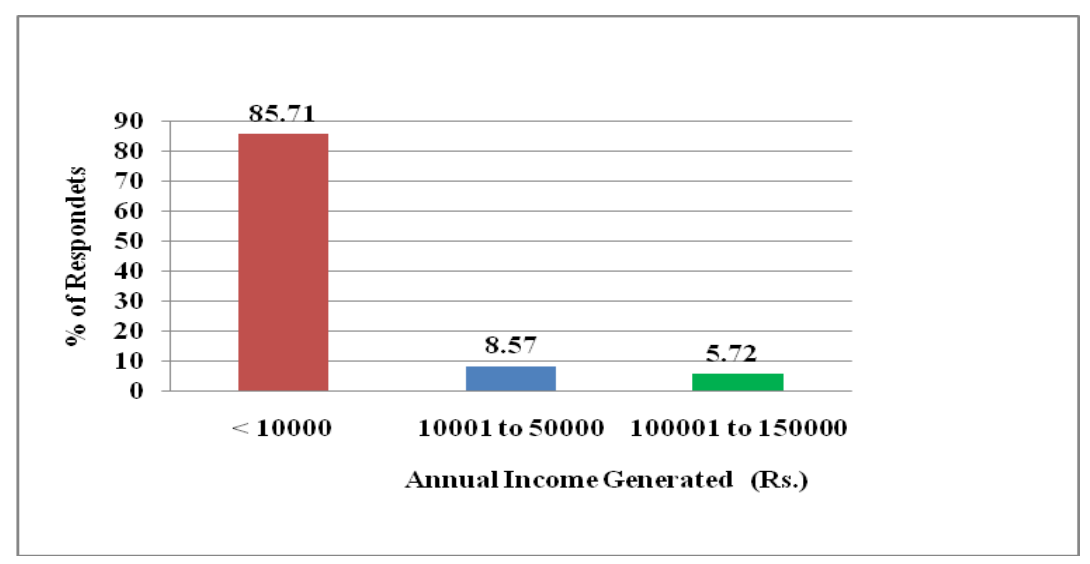


Graph.2 Distance traveled for income generation by using coconut climbing equipment

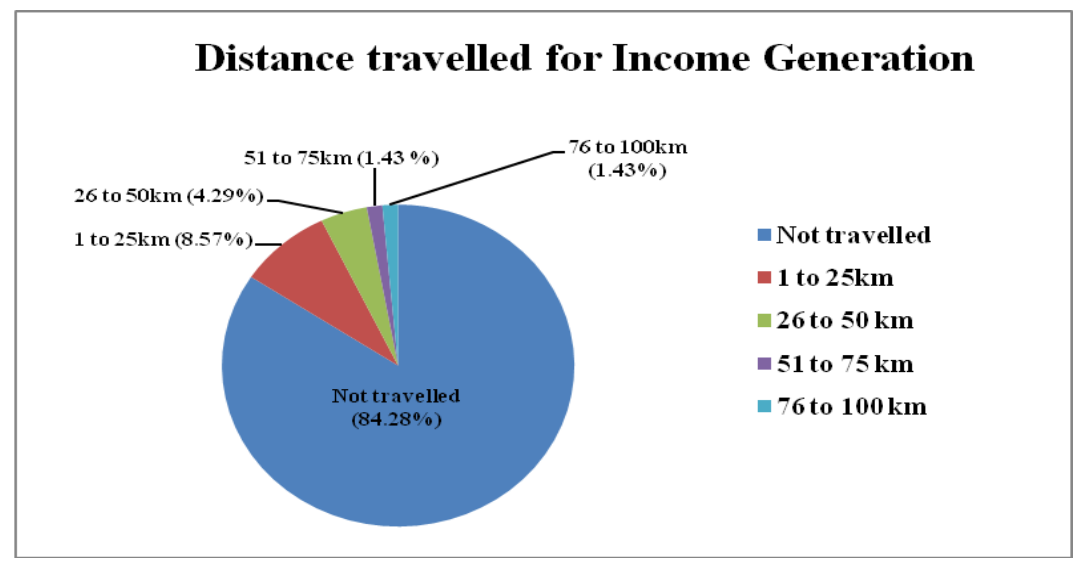

Graph.3 Constraints experienced by respondents in using coconut climbing equipment

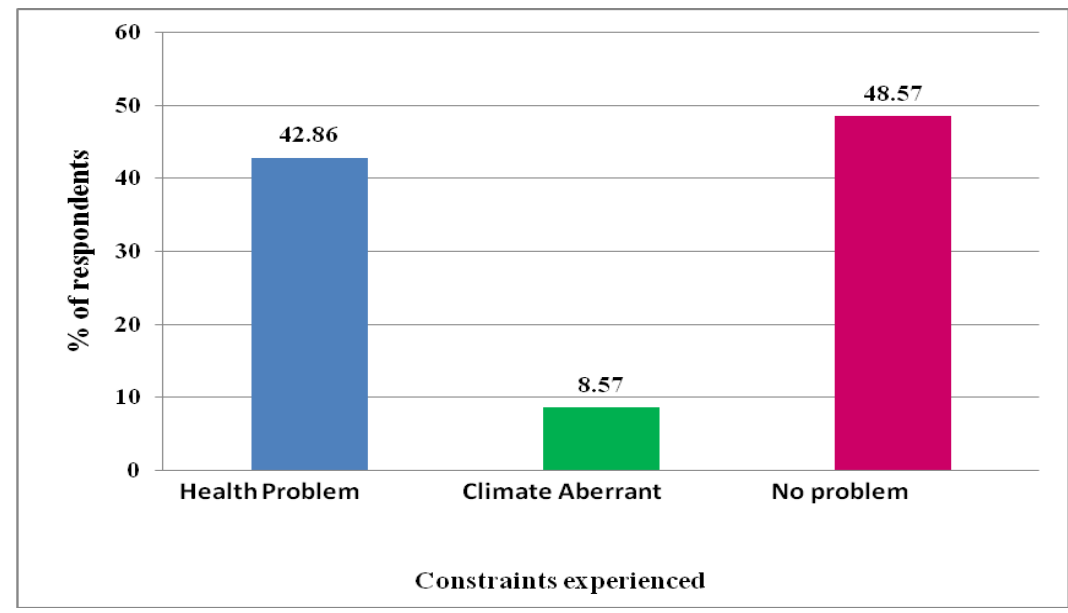

Photo: Youth trainee practicing using coconut climbing equipment, during training program.

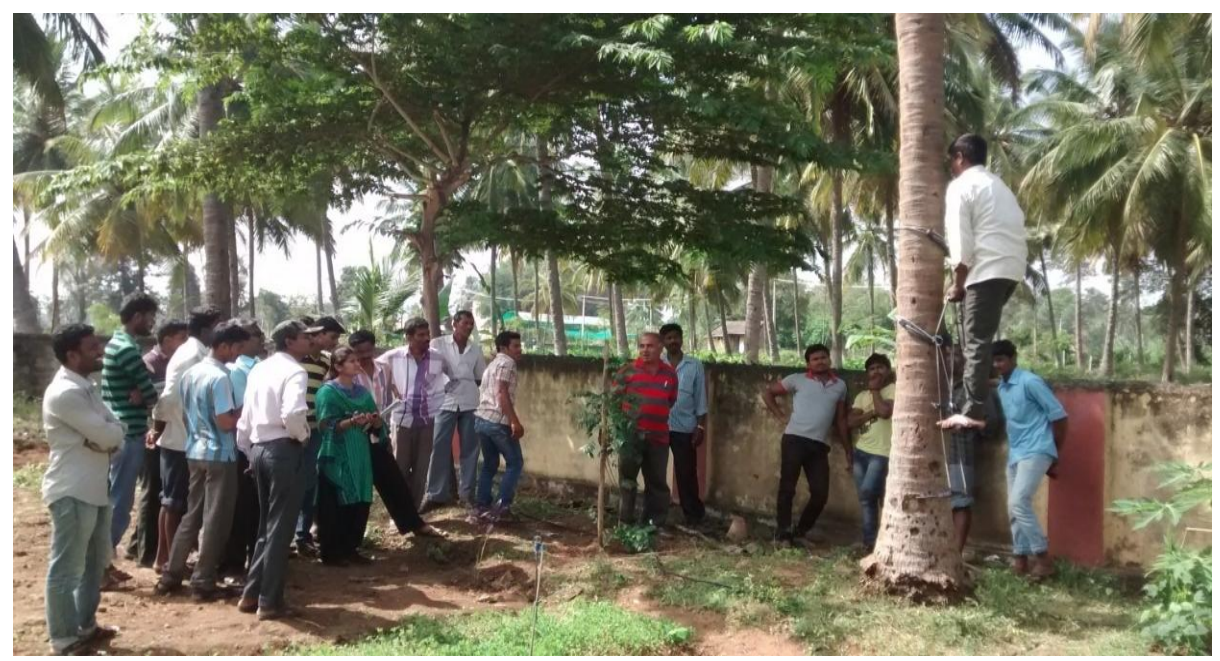


Association between income generation and land holding of the respondents

There was no significant association between income generation and land holding of respondents (Table-6, Chi square=0.62NS). The table implies that irrespective of land holdings the respondents had earned same income using the Coconut climbing equipment. Normally, marginal land holders might have used the climbing equipment outside their farm by visiting coconut gardens to earn the income and the big farmers might have used the equipment in their own coconut garden (the income accrued is not calculated) for their livelihood.

To conclude that, the selected three independent variables viz., family size, education level and land holding had no significant association with income generation in using of coconut climbing equipment. Thus, the alternate hypothesis of association between the dependent variable 'income generation' and the above three independent variables has been rejected.

The implication of study could be the income generation by using coconut climbing equipment is influenced by other factors that are not included in this study. Further, the income generation by using coconut climbing equipment also depends on the seasonal variations, climatic conditions, free time of the respondents, demand from coconut gardeners etc., to harvest the nuts. Very few respondents travelled long distance from their native place however, they can during the summer season as there could be better opportunities for harvesting of tender nuts. In this regard a further research needs to be conducted. The difficulties experienced by the respondents while using the equipment have to be taken in to cognizance of either to modify, by revalidating the equipment from the manufacturing agency or address remedial measures by conducting a workshop inviting the concerned stake holders.

\section{Acknowledgement}

The support and encouragement extended by the Directorate of Research, Senior Scientists and Head, KVK, Mandya, UAS, Bangalore is duly acknowledged for conducting the feedback study.

\section{References}

Adivi Reddy, A., 1977, Extension Education. Shree lakshmi press,Bapatla Andhra Pradesh. David J. Sheskin., 2011, Handbook of parametric and Non parametric statistical procedures $\left(5^{\text {th }}\right.$ edn). Chapman and Hall/CRC publications USA.

Jaganathan, D., Thamban, C., Subramanian, P and Jayashekhar, S., 2016, Production processing and marketing mechanism in coconut. ICAR- CPCRI, Kasaragod, Kerala: 66.

Jayale, P.S., 1992, A study on extent of adoption and sustainability horticulture crops advocated by horticultural department. M.Sc. (Agri.) Thesis, Maharashtra Agri. Univ, Parbhani (India).

Latha, K.B., 2003, A Critical analysis of Adoption level, Economic performance and Marketing channels of coconut growers in central dry zone of Karnataka, M.Sc. (Agri.) Thesis (Unpub), Univ. Agric. Sci., Bangalore.

Kerlinger, F.N., 1964, Foundations of Behavioral Research. Holt Rinehart and Winston, Inc., New York: 379.

Training Manual, 2013, FOCT: Coconut Palm Climbing and Plant Protection Training Programme Report, Krishi Vigyan Kendra, V.C. Farm, Mandya, Karnataka.

Yalesi, 2016, Why are rural youth leaving farming? Comments in 'Youth Agribusiness Leadership and Entrepreneurship summit innovation' held 29-31 March, in the Dakar, Senegal. 


\section{How to cite this article:}

Venkatesha, M., D. Raghupathi and Sanath Kumar, V. B. 2020. Perceived Impact of Coconut Climbing Equipment on Income Generation of Rural Youths in Karnataka India. Int.J.Curr.Microbiol.App.Sci. 9(09): 3428-3435. doi: https://doi.org/10.20546/ijcmas.2020.909.425 